\title{
Cultural Political Economy: on Making the Cultural Turn without Falling into Soft Economic Sociology
}

\section{Bob Jessop and Stijn Oosterlynck}

Abstract: This article explores the implications of making the cultural turn in the engagement of economic and political geography with issues of political economy. It seeks to steer a path between a fetishistic, reified economics that naturalizes economic categories and a soft economic sociology that focuses on the similarities between economic and other socio-cultural activities at the expense of the specificity of the economic. We show how combining critical semiotic analysis with an evolutionary and institutional approach to political economy offers one interesting way to achieve this goal. An evolutionary and institutional approach to semiosis enables us to recognize the semiotic dimensions of political economy at the same time as establishing how and why only some economic imaginaries among the many that circulate actually come to be selected and institutionalized; and Marxian political economy enables us to identify the contradictions and conflicts that make capital accumulation inherently improbable and crisis-prone, creating the space for economic imaginaries to play a role in stabilizing accumulation in specific spatiotemporal fixes and/or pointing the way forward from recurrent crises. The paper illustrates these arguments with a case study on the Flemish 'anchoring debate' as a specific regional economic development strategy. It concludes with a set of guidelines for the further development of cultural political economy.

Key words: Semiosis; critical discourse analysis; hegemony; cultural political economy; Belgium; accumulation strategy; state project; nationalism; regionalization;

Bob Jessop is Professor of Sociology and Director of the Institute for Advanced Studies at Lancaster University.

Stijn Oosterlynck is a post-doctoral research associate in the School of Geography, Manchester University. 


\section{Cultural Political Economy: on Making the Cultural Turn without Falling into Soft Economic Sociology}

This contribution aims to redirect the cultural turn(s) in economic and political geography by making and illustrating the case for a distinctive approach to 'cultural political economy' (hereafter CPE refers to this approach and not to the wider set of cultural turns in political economy). ${ }^{1}$ This combines concepts and tools from critical semiotic analysis with others from critical political economy to produce a distinctive post-disciplinary approach to the analysis of capitalist social formations (cf. Jessop and Sum 2001). While it is not demonstrated here, CPE can also be applied to noncapitalist economic and political orders by combining a critical analysis of the production of intersubjective meaning (i.e., semiosis) with concepts suited to such orders and their institutional dynamics. One of the key differences between CPE and other approaches that make a cultural turn is its explicit integration of the general evolutionary mechanisms of variation, selection, and retention into semiotic analysis and, in particular, its concern with the path-dependent co-evolution of the semiotic and extra-semiotic aspects of actually existing political economies. In other words, we take for granted the path-shaping potential of economic imaginaries (in their different forms and varying content) and seek to explain why only some economic imaginaries among the many that circulate actually come to be selected and institutionalized and thereby come to co-constitute economic subjectivities, interests, activities, organizations, institutions, structural ensembles, emergent economic orders and their social embedding, and the dynamics of economic performance. We also emphasize that these general evolutionary mechanisms are mediated in and through the distinctive forms and institutional dynamics of capitalism (or other forms of political economy) as well as through the general features of semiosis. Indeed, it seems that the relative importance of institutional materiality increases from the stage of variation in economic and political imaginaries through the stage when they are selectively translated into specific material practices and institutional dynamics to the stage when they are embodied in a structurally coherent set of social relations and a spatio-temporal fix compatible with continued accumulation (see below).

Combining the semiotic and extra-semiotic in this way facilitates two lines of investigation of particular relevance to economic, political, and cultural geography. 
First, given the infinity of meaningful communications and (mis)understandings enabled by semiosis, how do extra-semiotic as well as semiotic factors affect the variation, selection, and retention of particular instances of semiosis and their associated practices in ordering, reproducing and transforming capitalist social formations and their various spatio-temporal features? Second, given the contradictions, dilemmas, indeterminacy, and overall improbability of capitalist reproduction, especially during its recurrent crises, what role does semiosis play in construing, constructing, and temporarily stabilizing capitalist social formations at least within specific spatio-temporal fixes and their zones of relative stability even as it displaces and defers conflicts, contradictions, and crisis-tendencies elsewhere and/or into the future ${ }^{2}$ In regard to both questions, we argue, as noted above, that the relative weight of semiotic and extra-semiotic mechanisms changes over the analytically distinct, but frequently empirically overlapping, steps of variation, selection, and retention. After elaborating the general case for CPE, we illustrate it from the emergence, selection, and attempted implementation of two successive economic imaginaries that have informed economic policies in Belgium: the Belgian and Flemish 'anchoring' strategies. We conclude with a set of guidelines for the further development of cultural political economy.

\section{Cultural Political Economy}

Arguments in favour of 'cultural political economy' seem to have emerged in several contexts during the 1990s as part of and/or in response to the cultural turn. The present version was developed by scholars at Lancaster University ${ }^{3}$ drawing on a far wider range of sources. But it was prefigured in some major versions of critical political economy and in some 'old institutionalisms' and it has significant parallels in a range of contemporary disciplinary and trans-disciplinary endeavours. ${ }^{4}$ Among recent geographical studies, for example, we can note the contrasting approaches of Barnett (2004), Crang (1997), Hudson (2004), Mitchell (2000), Sayer (2001), and Thrift (2004). Our CPE approach has three defining features. First, like other currents in evolutionary and institutional political economy and unlike the more usual generic studies of semiosis, CPE opposes transhistorical analyses, insisting that both history and institutions matter. This is where the strategic-relational dialectic of pathdependency and path-shaping and its associated emphasis on the evolutionary 
mechanisms of variation, selection, and retention (Campbell 1969) have a key role in shaping the dynamics of semiosis. Second, unlike many currents in evolutionary and institutional political economy but like other variants of cultural materialism, CPE takes the cultural turn seriously, highlighting the complex relations between meanings and practices. For the production of intersubjective meaning is crucial to the description, understanding, and explanation of economic and political conduct just as it is for other types of behaviour and their emergent properties. And, third, building on these two features, CPE focuses on the co-evolution of semiotic and extra-semiotic processes and their conjoint impact on the constitution and dynamic of capitalist formations. This general approach can be re-stated in terms of four broad claims about the role of semiosis in the critique of political economy.

Ontologically, semiosis has a key role in the overall constitution of specific social objects and social subjects and, a fortiori, in their co-constitution and co-evolution in wider ensembles of social relations. Thus CPE rejects two related tendencies in orthodox political economy: (a) the tendency to naturalize or reify its theoretical objects (such as land, machines, the division of labour, production, money, commodities, the information economy); and (b) the tendency to offer thin accounts, at most, of how subjects and subjectivities are formed and how different modes of calculation emerge, come to be institutionalized, and get modified. For CPE, technical and economic objects are always socially constructed, historically specific, more or less socially embedded in - or disembedded from - broader networks of social relations and institutional ensembles, more or less embodied and 'embrained' in individual actors, and require continuing social 'repair' work for their reproduction. The same points hold for the objects of orthodox political science and (neo-)realist international relations theory. The former tends to treat the state as a set of governmental institutions used by state managers and other political forces to pursue interests that are objectively grounded in their respective social positions. Realist and neo-realist international relations theory also naturalizes interests in explaining the necessary logic of state action. In contrast, the Lancaster CPE approach follows Marx, Gramsci, and Poulantzas (among others) in studying the state in its inclusive sense ('political society + civil society') as a social relation. This approach regards state power as the discursively- and institutionally-mediated condensation of a changing balance of forces. It examines struggles to shape the identities, 
subjectivities, and interests of the forces engaged in political struggle as well as to transform the state system and its various selectivities. Moreover, in revealing the socially constructed nature of the phenomena of political economy, CPE involves a form of political intervention that goes beyond Ideologiekritik (which serves at best to uncover the ideal and material interests behind specific meaning systems and ideologies) to explore the semiotic and extra-semiotic mechanisms involved in selecting and consolidating the dominance and/or hegemony of some meaning systems and ideologies over others (see below).

Epistemologically, inspired by the Marxian critique of political economy, our approach to CPE not only critiques the categories and methods of orthodox political economy but also emphasizes the contextuality and historicity of all claims to knowledge. It follows that a self-consistent CPE calls for reflexivity on the part of social scientists about the conditions of their own practices. At the same time, in stressing the materiality of social relations and their emergent properties, CPE aims to avoid the temptations of pure social constructivism, according to which social reality is reducible to participants' meanings and understandings of their social world. This sort of reductionism generates an arbitrary account of the social world that ignores the unacknowledged conditions of action as well as the many and varied emergent properties of action that go un- or mis-recognized by the relevant actors. It also ignores the many and varied struggles to transform the conditions of action, actors' meanings and understandings, and to modify emergent properties. In short, CPE notes both the constitutive role of semiosis and the emergent extra-semiotic features of social relations and their impact on capacities for action and transformation.

Methodologically, CPE combines concepts and tools from critical semiotic analysis with those from critical political economy. Semiosis is an umbrella term for different approaches to the cultural turn insofar as they assume both that semiosis is causally efficacious as well as meaningful. This implies that actual events and processes and their emergent effects can be explained, at least in part, as well as interpreted in terms of semiosis. Thus CPE studies the role of semiotic practices not only in the continual (re-)making of social relations but also in the contingent emergence (variation), privileging (selection), ongoing realization (retention), and subsequent reinforcement through structural coupling (consolidation) of their extra-semiotic 
properties. It is the continuing interaction between the semiotic and extra-semiotic in a complex co-evolutionary process of variation, selection, and retention that gives relatively successful economic and political imaginaries their performative, constitutive force in the material world. Our case study illustrates this below (for other Lancaster examples, see Jessop 2004; Sum 2004, 2005).

Substantively, CPE affirms the overall complexity of the social world and the cognate importance of complexity reduction as a condition of social action. Adopting a strategic-relational approach to this process, it assumes that complexity reduction involves discursively-selective 'imaginaries' and structurally-selective institutions. Imaginaries are semiotic systems that provide the basis for the lived experience of an inordinately complex world; institutions provide the means of embedding lived experience in broader social relations and, perhaps, rendering it consistent across different social spheres. Transferring these abstract ideas to what orthodox economics misleadingly describes as the macro-level, CPE distinguishes the 'actually existing economy' as the chaotic sum of all economic activities (broadly defined as concerned with the social appropriation and transformation of nature for the purposes of substantive provisioning) ${ }^{5}$ from the 'economy' (or, better, 'economies' in the plural) as an imaginatively narrated, more or less coherent subset of these activities occurring within specific spatio-temporal frameworks. The totality of economic activities is so unstructured and complex that it cannot be an object of effective calculation, management, governance, or guidance. Instead such practices are always oriented to subsets of economic relations (economic systems, subsystems, or ensembles) that have been semiotically and, perhaps organizationally and institutionally, fixed as appropriate objects of intervention.

We argue that economic imaginaries have a crucial constitutive role in this regard. An economic imaginary is a semiotic order, i.e., a specific configuration of genres, discourses and styles and, as such, constitutes the semiotic moment of a network of social practices in a given social field, institutional order, or wider social formation (Fairclough 2003). Thus an economic imaginary (re-)articulates various genres, discourses, and styles around a particular conception of the economy and its extraeconomic conditions of existence. Economic imaginaries are always selectively defined - due to limited cognitive capacities and to the discursive and material biases 
of specific epistemes and economic paradigms. They typically exclude elements usually unintentionally - that are vital to the overall performance of the subset of economic (and extra-economic) relations that have been identified. Such exclusions limit in turn the efficacy of economic forecasting, management, planning, guidance, governance, etc., because such practices do not (indeed, cannot) take account of excluded elements and their impact. Moreover, if they are to prove more than 'arbitrary, rationalistic, and willed' (Gramsci 1971: 376-7), these imaginaries must have some significant, albeit necessarily partial, correspondence to real material interdependencies in the actually existing economy and/or in the relations between economic and extra-economic activities. Similar arguments would apply, with appropriate changes, to so-called meso- or micro-level economic phenomena, such as industrial districts or individual enterprises (see below).

Imagined economies are discursively constituted and materially reproduced on many sites and scales, in different spatio-temporal contexts, and over various spatiotemporal horizons. They extend from one-off transactions through stable economic organizations, networks, and clusters to 'macro-economic' regimes. While massive scope for variation typically exists at an individual transactional level, the medium- to long-term semiotic and material reproduction requirements of meso-complexes and macro-economic regimes narrow this scope considerably. The recursive selection of semiotic practices and extra-semiotic processes at these scales tends to reduce inappropriate variation and to secure the 'requisite variety' (constrained heterogeneity rather than simple uniformity) that supports the structural coherence of economic activities. Indeed stable semiotic orders, discursive selectivities, social learning, pathdependencies, power relations, patterned complementarities, and material selectivities all become more significant, the more that material interdependencies and/or issues of spatial and intertemporal articulation increase in and across diverse functional systems and the lifeworld. Yet this growing set of constraints also reveals the fragility and, indeed, improbability of the smooth reproduction of complex social orders. This highlights the importance of retaining an appropriate repertoire of semiotic and material resources and practices that can be flexibly and reflexively deployed in response to emerging disturbances and crises (cf. Grabher 1994). 
Economic imaginaries at the meso- and macro-levels develop as economic, political, and intellectual forces seek to (re)define specific subsets of economic activities as subjects, sites, and stakes of competition and/or as objects of regulation and to articulate strategies, projects and visions oriented to these imagined economies. These forces tend to manipulate power and knowledge to secure recognition of the boundaries, geometries, temporalities, typical economic agents, tendencies and counter-tendencies, distinctive overall dynamic, and reproduction requirements of different imagined economies (Daly 1991; Miller and Rose 1993). They also seek to develop new structural and organizational forms that will help to institutionalize these boundaries, geometries, and temporalities in an appropriate spatio-temporal fix that can displace and/or defer capital's inherent contradictions and crisis-tendencies. However, by virtue of competing economic imaginaries, competing efforts to institute them materially, and an inevitable incompleteness in the specification of their respective economic and extra-economic preconditions, each 'imagined economy' is only ever partially constituted. There are always interstitial, residual, marginal, irrelevant, recalcitrant and plain contradictory elements that escape any attempt to identify, govern, and stabilize a given 'economic arrangement' or broader 'economic order' (Jessop 2002). These provide important sources of resistance and help preserve a reservoir of semiotic and material resources that enable dominant systems (through the agency of their associated social forces) to adapt to new challenges through their re-articulation and recombination in the service of power.

Relatively successful economic imaginaries have their own, performative, constitutive force in the material world. ${ }^{6}$ For their operation presupposes a substratum of substantive economic relations and instrumentalities as their elements; in addition, where an imaginary is successfully operationalized and institutionalized, it transforms and naturalizes these elements and instrumentalities into moments of a specific economy with specific emergent properties. For economic imaginaries identify, privilege, and seek to stabilize some economic activities from the sum of economic relations and turn them into objects of observation, calculation, and governance. Technologies of economic governance, operating sometimes more semiotically, sometimes more materially, ${ }^{7}$ constitute their own objects of governance rather than governing already pre-constituted objects (Jessop 1990, 1997). 
Taking for granted the general principles of critical semiotic analysis (Fairclough 2003) to focus on broader evolutionary and institutional issues in political economy, we note that there is constant variation, witting or unwitting, in apparently routine social practices. This poses questions about the regularization of practices in normal conditions and about possible sources of radical transformation, especially in periods of crisis. The latter typically lead to profound cognitive and strategic disorientation of social forces and a corresponding proliferation in discursive interpretations and proposed material solutions. Nonetheless the same basic mechanisms serve to select and consolidate radically new practices and to stabilize routine practices. Simplifying the analysis of evolutionary mechanisms given in Fairclough et al. (2004) and extending it to include material as well as semiotic factors, a first cut at specifying these mechanisms suggests the following:

a) Continuing variation in discourses and practices, whether due to their incomplete mastery, their skilful adaptation in specific circumstances, new challenges or crises, or other semiotic or material causes.

b) Selection of particular discourses (the privileging of just some available, including emergent, discourses) for interpreting events, legitimizing actions, and (perhaps self-reflexively) representing social phenomena. Semiotic factors operate here by influencing the resonance of discourses in personal, organizational and institutional, and broader meta-narrative terms and by limiting possible combinations of semiosis and semiotic practices in a given semiotic order. Material factors also operate here through conjunctural or institutionalized power relations, path-dependency, and structurally-inscribed selectivities.

c) Retention of some resonant discourses (e.g., inclusion in an actor's habitus, hexis, and personal identity, enactment in organizational routines, integrated into institutional rules, objectification in the built environment, material and intellectual technologies, and articulation into widely accepted accumulation strategies, state projects, or hegemonic visions). The greater the range of sites (horizontally and vertically $)^{8}$ in which resonant discourses are retained, the greater is the potential for effective institutionalization and integration into patterns of structured coherence and durable compromise. The constraining influences of complex, reciprocal interdependences will also recursively affect the scope for retaining resonant discourses. 
d) Reinforcement insofar as procedural devices exist that privilege these discourses and associated practices and also filter out contrary discourses and practices. This can involve both discursive selectivity (e.g., genre chains, styles, identities) and material selectivity (e.g., the privileging of certain dominant sites of discourse in and through structurally-inscribed strategic selectivities of specific organizational and institutional orders). Such mechanisms recursively strengthen appropriate genres, styles, and strategies and selectively eliminate inappropriate alternatives and are most powerful where they operate across many different sites to promote complementary discourses within the wider social ensemble.

e) Selective recruitment, inculcation, and retention by relevant social groups, organizations, institutions, etc., of social agents whose predispositions fit maximally with the preceding requirements.

This list emphasizes the role of semiosis and its material supports in securing social reproduction through the selection and retention of mutually supportive discourses. Conversely, the absence or relative weakness of one or more of these semiotic and/or extra-semiotic conditions may undermine previously dominant discourses and/or block the selection and retention of appropriate innovative discourses. This absence or weakness is especially likely in periods of profound disorientation due to rapid social change and/or crises that trigger major semiotic and material innovations in the social world. We should note here that the semiotic and extra-semiotic space for variation, selection, and retention is contingent, not pre-given. This also holds for the various and varying semiotic and material elements whose selection and retention occurs in this 'ecological' space. In a complex world there are many sites and scales on which such evolutionary processes operate and, for present purposes, what matters is how local sites and scales come to be articulated to form more global (general) sites and scales and how the latter in turn frame, constrain, and enable local possibilities (Wickham 1987). These interrelations are themselves shaped by the ongoing interaction between semiotic and extra-semiotic processes.

\section{Integrating Critical Semiotic Analysis into Political Economy}

A particularly interesting moment in the development of economic imaginaries is the emergence of crises affecting economic identities and performance. A CPE approach 
implies that crisis is never a purely objective process or moment that automatically produces a particular response or outcome. Instead a crisis emerges when established patterns of dealing with structural contradictions, their crisis-tendencies, and dilemmas no longer work as expected and, indeed, when continued reliance thereon may even aggravate the situation. Crises are most acute when crisistendencies and tensions accumulate across several interrelated moments of the structure or system in question, limiting room for manoeuvre in regard to any particular problem. Changes in the balance of forces mobilized behind and across different types of struggle also have a key role in intensifying crisis-tendencies and in weakening and/or resisting established modes of crisis-management (Offe 1984: 3564). This creates a situation of more or less acute crisis, a potential moment of decisive transformation, and an opportunity for decisive intervention. In this sense, a crisis situation is unbalanced: it is objectively overdetermined but subjectively indeterminate (Debray 1973: 113). And this creates the space for determined strategic interventions to significantly redirect the course of events as well as for attempts to 'muddle through' in the (perhaps forlorn) hope that the situation will resolve itself in time. In short, crises are potentially path-shaping moments.

Such path-shaping is mediated semiotically as well as materially. Crises encourage semiotic as well as strategic innovation. They often prompt a remarkable proliferation of alternative visions rooted in old and new semiotic systems and orders. Many of these will invoke, repeat, or re-articulate established genres, discourses, and styles; others may develop, if only partially, a 'poetry for the future' that resonates with new potentialities (Marx 1996: 32-34). Which of the proliferating alternatives, if any, is eventually selected, retained and consolidated is mediated in part through discursive struggles to define the nature and significance of the crisis and what might follow from it. If the crisis can be interpreted as a crisis in the existing economic order, then minor reforms and a passive revolution will first be attempted to re-regularize that order. If this fails and/or if the crisis is already interpreted initially as a crisis of the existing economic order, a discursive space is opened to explore more radical changes. In both cases conflicts also concern how the costs of crisis-management get distributed and the best policies to escape from the crisis. 
In periods of major social restructuring, diverse economic, political, and socio-cultural narratives may intersect as they seek to give meaning to current problems by construing them in terms of past failures and future possibilities. Different social forces in the private and public domains propose new visions, projects, programmes, and policies and a struggle for hegemony grows. The plausibility of these narratives and their associated strategies and projects depends on their resonance (and hence capacity to reinterpret and mobilize) with the personal (including shared) narratives of significant classes, strata, social categories, or groups affected by the postwar economic and political order. Moreover, although many plausible narratives are possible, their narrators will not be equally effective in conveying their messages and securing support for the lessons they hope to draw. This will depend on the prevailing 'web of interlocution'9 and its discursive selectivities, the organization and operation of the mass media, the role of intellectuals in public life, and the structural biases and strategically selective operations of various public and private apparatuses of economic, political, and ideological domination. ${ }^{10}$ Such concerns take us well beyond a concern for narrativity and/or the constraints rooted in specific organizational or institutional genres, of course, into the many extra-discursive conditions of narrative appeal and of stable semiotic orders. That these institutional and meta-narratives have powerful resonance does not mean that they should be taken at face value. All narratives are selective, appropriate some arguments, and combine them in specific ways. In this sense, then, one must consider what is left unstated or silent, what is repressed or suppressed in official discourse.

The strategic-relational analysis of structure and agency in struggles over hegemony rests on the general evolutionary distinction between variation, selection, and retention. First, there is continuing variation in discourses as actors intentionally or unintentionally redefine the sites, subjects, and stakes of action and articulate innovative strategies, projects and visions. This is especially likely during crises, which often produce profound strategic disorientation and a proliferation of alternative discourses. Second, while most of this variation is arbitrary and short-lived, lacking long-term consequences for overall social dynamics, some semiotic innovations are selected. This occurs because they resonate discursively with other actors and social forces and/or because they are reinforced through various structural mechanisms. So 
we must explore the discursive and extra-discursive mechanisms that select some discourses for further elaboration and effective articulation with other discourses.

Discourses are most powerful where they operate across many sites and scales and can establish and connect local hegemonies into a more encompassing hegemonic project. These discourses will be retained (discursively reproduced, incorporated into individual routines, and institutionally embedded) when they are able to reorganize the balance of forces and guide supportive structural transformation. Although any given economic or political imaginary is only ever partially realized, those that succeed, at least in part, have their own performative, constitutive force in the material world - especially when they correspond to (or successfully shape) underlying material transformations, can mobilize different elites to form a new power bloc, can organize popular support, disorganize opposition, and marginalize resistance. They will be most successful when they establish a new spatiotemporal fix that can displace and/or defer capital's inherent contradictions and crisistendencies in the international political economy. In short, discourses and their related discursive chains can generate variation, have selective effects - reinforcing some discourses, filtering others out, and contribute to the differential retention and/or institutionalization of social relation through the recursive selection of certain genres, performances, and strategies (Jessop 2004).

\section{Economic Imaginaries and Region-Building}

'The new regionalism' is an umbrella term for research on how regions are constituted by, and constitutive of, social, economic and political relations and identities, especially in response to globalization (Paasi 2002). This poses the question of what constitutes a region or regional economy because, as Jones notes, the region has become a 'slippery and somewhat meaningless concept for discussing differently scaled and territorialized economic, social, cultural and political assemblages' (2004: 62). Approaching regions as historically and geographically contingent entities offers an escape from this conundrum by situating them in a multiscalar framework of administrative structures, functional economic and social ties and meanings invested in them by residents and outsiders. This solution can be enhanced by taking regional imaginaries and identities seriously as potentially key 
factors in the co-constitution of the political and economic during the creation and institutionalization of regional economies (Agnew 2000; Jones 2004; Paasi 1991). We follow this approach in our study of Belgian and Flemish anchoring strategies, which rest on different conceptions of the Belgian space economy and its internal differentiation and have very different linkages with extra-economic values and identities. In exploring the selection of these strategies we show that history and institutions matter because of the changing articulation, instantiation, and spatial implications of three cleavages in the Belgian social formation: religion, language, and class. For economic imaginaries have been shaped by the social embedding of the economic order within this broader formation and successful pursuit of their associated strategies depends heavily on their extra-economic contexts and supports as well as on their purported economic feasibility. In this sense, CPE can contribute to the understanding of new regionalism because it promises to integrate semiotic factors into the analysis of the institutionalization of regional economies without falling into 'soft economic sociology'. The latter tends to limit the cultural turn to the role of cultural factors as business assets in underpinning regional growth strategies and regional competitiveness and to ignore issues of power (cf. Lovering 2001).

Our case study (conducted by Stijn Oosterlynck) develops a CPE account of the attempted restructuring of the Belgian space economy ${ }^{11}$ in response to globalization and its associated relativization of scale, ${ }^{12}$ focusing in this context on the Belgian 'anchoring' concept and its subsequent translation into a distinctive but ambivalent Flemish 'anchoring strategy'. In particular, it explores changing political and economic imaginaries, their mobilization of alternative ideas of economic nationalism, and the resulting tensions/convergences with more general political and economic restructuring. Moreover, drawing on the distinction between variation, selection, and retention, it shows that, even when certain regional imaginaries are discursively selected from a wider array and are translated into regional strategies pursued by major social forces, they may prove 'arbitrary, rationalistic and willed'. In other words, they will not be retained (institutionalized) in a coherent set of sustainable, regionbuilding apparatuses and policies because they lack the necessary material and discursive supports to ensure their effective implementation and integration into a reproducible economic and political order. In such cases CPE suggests that there will be a renewed search for a plausible and effective imaginary. This is certainly the 
case in Flanders, where the newly hegemonic imaginary, yet to be properly tested, appears to be liberalization (Oosterlynck 2006).

The development of the Flemish region is rooted in the distinctive articulation of two structural trends in Belgian history: (a) territorialization of the Belgian language conflict and (b) the changing forms of regional uneven economic development. The two economic imaginaries (see below) that have proved most resonant in the recent anchoring debate are rooted in these historical developments and have contributed to the rise of the Flemish space economy as an object of strategic intervention without, however, transforming it in line with the strategic objectives of either of the corresponding anchoring strategies. We seek to explain this in CPE terms below.

Territorialization of Belgium's language problem and uneven economic development

The 'Belgian condition' is commonly analysed in terms of three cleavages: language, religion and class (Huyse 1980). While it is tempting to take these cleavages for granted as primordial or objectively grounded in economic relations, a CPE approach interprets them as socially constituted bases of personal and collective identity, social practices, and social mobilization. Their durability as alternative lines of cleavage nonetheless depends on their embedding in material as well as discursive practices that are changing and changeable and whose relative weight and structural coupling can vary (and, indeed, be made to vary through appropriate strategic interventions) in space-time. Religion has been marginal in the anchoring debate but it was (and to some extent remains) a major constitutive force in Belgian life through the powerful material and ideological influence of the Christian church within the education system, in labour organization in Flanders (as opposed to its minor influence over the Walloon labour class), its support for Belgian francophone nation-building, and its links to moderate Flemish nationalism. Language is significant for the state as well as civil society because of the traditional strong francophone bias in recruiting state managers, elite formation more generally, and the organization (and fracturing) of power blocs and subaltern groups. And class is grounded, of course, in social relations of production that are differentially articulated with, and imprinted by, religious and linguistic differences. 
These considerations open the space to explore the discursive and material factors and processes that shape the relative weight and differential articulation of these cleavages and their changing significance for social action in particular conjunctures. A CPE perspective would ask how social groups come to be constituted as collective subjects with their own distinctive modes of calculation - whether these are discursively and materially based in class, religious or ethno-linguistic differences or some combination thereof - and how these identities become consolidated as bases of social mobilization. An adequate answer requires a more critical and constructivist approach to the genealogy of these antagonisms. This is certainly more than we get in Mandel's well-known analysis (1963) of the dialectic of region and class in Belgium. For, while we share his concern with the uneven economic development of the capitalist space economy, Mandel fails to examine how regions and their inhabitants were imagined and institutionalised as objects of economic, political, or social and as subjects whose primary identity was as class, religious, or linguistic subjects. He pre-supposes instead the historically immanent unification of the Belgian working class through the general logic of proletarianization and claims that this was blocked in the case of Flanders as regional conflicts intensified.

To show that there was nothing pre-given, let alone unchanging, about these three cleavages, we show how each emerged and has been transformed over time and how all three have come to be articulated in different ways at different times. We also show that changes in their relative significance and structural coupling are mediated not only through emergent, unintended, and, perhaps, unacknowledged structural shifts but also through the mobilization of relevant social forces around competing social imaginaries. This requires a stylized CPE account of Belgian political economy as the history of the making, unmaking and remaking of collective subjects, their uneven institutionalisation, and the eventual consolidation into power structures. We address economic, linguistic, and religious identities in turn without seeking to imply through this order of presentation that the economy is somehow determinant, whether in the first or even last instance.

From its emergence as a potential object of calculation and governance with the formation of an independent Belgian state in 1830, the Belgian economy experienced highly uneven development. High energy transport costs and a pivotal role for the 
steel industry in economic development stimulated the rapid industrialization of the coal-rich Walloon provinces with some spillover into light industry and consumption goods (Vandermotten et al., 1990). In contrast, the Flemish provinces remained largely rural and underdeveloped, except for some industrial small pockets around Ghent (textiles) and Antwerp (port facilities). The seeds of change were planted in the 1880 economic crisis, however, which was concentrated in Wallonia. This destroyed the latter's light industrial and consumer goods sectors and the resulting lack of diversification and investment became major factors in Walloon economic decline in the $20^{\text {th }}$ century. The trend towards uneven development was intensified through the second industrial revolution following the Great Depression (1929-32) because this particularly benefited the Antwerp region without bringing much advantage to Wallonia. While the former gained from investments in non-ferrous metals, carbon- and petro-chemicals, and electricity generation linked partly to its strategic port location (Vandermotten, Saey and Kesteloot 1990). The selective nature of this industrialization wave and its close ties to the interests of frenchified national capital prevented the rise during this period of an autonomous Flemish space economy and an autonomous Flemish bourgeoisie. At the same time, the legacies of previous rounds of investment in Wallonia left little social or geographical room for an industrial restructuring policy. Accordingly Belgian national financial capital sought a new spatial fix in response to lack of investment opportunities in this regard by resorting to foreign investments, mainly in the Congo and China (cf. the general model in Harvey 1982). Paradoxically this pattern of uneven development between the Flemish and Walloon regions saw the final integration of a Belgian space economy based on the Antwerp-Brussels-Charleroi industrial axis. This was achieved through the centralization of capital on the national level, in which the Belgian holding company, Sociéte Générale, played a key role, so that it viewed the whole of the Belgian economy as a relatively unified object of economic calculation shaped by the dynamic of the so-called A-B-C axis.

Regarding language, although a majority of the population still spoke various Flemish dialects when the Belgian state was created in 1830, the new government decreed that French would be the sole official language. This reflected the interests of the largely francophone elite, including frenchified 'Flemings' (Murphy 1988). At this time the language division was more social than geographical because the inhabitants of 
Flanders and Wallonia saw themselves either as commoners with largely local identities or else as members of the national elite (Murphy 1988; Reynebeau 1995). The resulting primacy of social over regional-territorial division is reflected in the fact that the 'Flemish movement' that emerged soon after independence among middle class intellectuals pursued a liberal struggle for individual language rights and increased bilingualism rather than calling for segregation into unilingual spaces. Only in the early $20^{\text {th }}$ century did the latter approach replace the liberal conception, which had envisaged the use of French in Flemish provinces. The turn against bilingualism was due to frustration with the slow progress of the language laws, the diffusion of regional-linguistic ideas because of earlier legislative and political developments, the introduction of universal male suffrage which increased the political power of the Flemings, and the associated wish to strengthen the Flemish movement's social base by stressing regional commonalities and continuities at the expense of national integration under francophone dominance. It is important to note here that the regionalization of the language question was contingent on crucial political factors rather than something inscribed at birth in the very nature of the Belgian state.

After the Second World War, ethno-linguistic consciousness expanded as issues only loosely linked with language gained regional sensitivity. The Royal Question and the second School Struggle are emblematic here. First, a sharp political controversy emerged in 1946 about King Leopold III's political stance before and during the war (Reynebeau 2005). This was essentially an ideological confrontation between Catholics and atheist Socialists and turned on the strategy of the CVP, the Belgian catholic (later Christian Democrat) party, to use its support for the King to win an absolute political majority in the Belgian state by mobilizing the Flemish majority in Belgium as a whole and the Catholic majority in Flanders. A referendum was held in March 1950 on whether the King should step down or not; it gave Leopold III 57\% of the votes. This seemed to divide the country into a conservative and catholic Flanders and an atheist and leftist Wallonia but the division between urban-industrial and rural-agrarian groupings was actually more significant. For, while a majority of the Flemings voted for the King, a majority of Walloons and Brussellois voted against. The ensuing stalemate was only resolved when Leopold III abdicated, signifying the failure of the Catholics' absolute majority strategy. Yet Flemish 
nationalists often present this outcome as a defeat of the Flemish majority at Walloon hands, reinforcing thereby claims about the repressive 'francophone' Belgian state.

The 'second school struggle' was precipitated when the Christian-democrats (CVP), the biggest political party in Belgium, were ousted in 1954 by a socialist-liberal coalition government (Reynebeau 1995; Reynebeau 2005; Witte 1997). This reversed its predecessor's pro-Catholic education policies, reactivating a crucial line of conflict between Belgium's opposing political-ideological forces rooted in the nineteenth century competition between two cultural projects associated with the liberal (and later Socialist) party and the Catholic - later Christian-democrat - party respectively. One project was to build a secular national state, the other to promote the values of the catholic majority. This conflict was alleviated by a compromise that laid the basis of the Belgian pillarisation system. Public finance was granted to develop a catholic socio-cultural pillar, allowing the Church to maintain ideological control over its faith community, in return for its ceasing to contest Belgian nationand state-building. The post-war development of mass education enabled Socialists and Liberals to break the resulting Catholic dominance in education by redirecting public finance towards state education. The Catholic pillar responded by mobilizing its grassroots in hard extra-parliamentary action. The dispute was resolved through a school pact in 1958 that increased resources for free (i.e., Catholic) education and relaxing controls on the expansion of state education. While this mainly an ideological conflict, it had a strong regional dimension because Catholics were overrepresented in Flanders and Socialists in Wallonia.

Such issues show how ideological conflicts among Socialists, Liberals and Catholics could become intertwined with language politics (Huyse 1980; Reynebeau 1995). The latter gradually developed into a conflict between geographically separated communities defending different societal models. In particular, once the School Pact significantly reduced tensions between the Catholic and secular groupings, political energy in the 1960s and 1970s could turn to socio-economic issues and ethnolinguistic conflicts (Witte 1997). These two conflicts converged in the strikes against the Unity Law in 1960 and 1961, prompted by the severe economic crisis of the 1950 s and the shifting of the economic centre of gravity in the ABC-axis towards Flanders due to massive postwar investment in this region by multinationals 
(Vandermotten, Saey and Kesteloot 1990). These developments finally led the Walloon working class to interpret structural economic decline in terms of a growing polarization between Flanders' dominance and Wallonia's semi-peripheral status.

The strikes against the Unity Law fused reactions to this regional uneven economic development with the ongoing territorialization of the language conflict. The Unity Law was proposed in 1960 by the government of the Flemish Christian-democrat Eyskens. It envisaged drastic cuts in social expenditures and higher indirect taxation to finance industrial modernisation and economic expansion, which were deemed necessary to overcome the long-term economic crisis (Eyskens 1988; Witte 1997). The proposal triggered a five-week general strike, paralysing industry in Wallonia and spreading to the Flemish ports of Antwerp and Ghent. The strike's centre of gravity was in the heavy industries and in Wallonia. While the Christian trade union ACV, which is dominant in Flanders, supported 'their' minister, the ill-prepared Flemish socialist trade unionists and national socialist party never recognized the strike. Disillusioned by the Flemish reluctance to participate in the strike, some Walloon strike leaders despaired at what they saw as the stranglehold of a Flemish conservative and catholic parliamentary majority. In a decisive turn, they campaigned for the tools to pursue autonomous reforms of the Walloon industrial structure and thereby initiated the fusion of regional and labour movement struggles. This gave a decisive political-economic content to divisions that had previously been expressed in Wallonia in terms of Flemish 'encroachment' on the status of the French language. This shift also led to a turn from defence of the linguistic status quo to an offensive strategy to advance Walloon politico-economic interests in the new conjuncture.

This conjuncturally-determined fusion of the Walloon working classes and the Walloon federalist movement was decisive in shaping the contrasting imaginaries that came to inform Flemish and Walloon regionalisation strategies. In sum, the combined force of regional uneven economic development and territorialization of the language conflict triggered political and economic communitarianism on regional lines. This shift gradually led to Belgium's legal transformation from a unitary into a federal state between 1970 and 1993 (Van Istendael 1993) and provides the context for the Flemish anchoring debate. This is one of the most important debates concerning Flemish economic strategies in the last two decades and we now show 
how the cultural and institutional resources developed during two centuries of Belgian history have been (and are still being) articulated into two economic imaginaries as competing bases for constructing the Flemish regional space economy.

\section{The anchoring debate}

In the late 1980s Belgium's traditional welcome to multinational capital turned to fear about losing economic self-determination. This crystallised in the Belgian anchoring debate, triggered when the main Belgian holding company, Société Générale (hereafter SG), suffered a share raid in January 1988 by Carlo de Benedetti, an Italian investor. The debate concerned whether national decision-making power over the economic infrastructure is desirable and necessary to maintain a strong economy and fund welfare (Brockmans 1995, Daems and Van de Weyer 1993, Geens 1995). In this sense it turned on competing conceptions of the Belgian economy, its insertion into the European, Atlantic, and global economic order, the changing nature of economic competitiveness and its extra-economic conditions of existence, and the extent to which the 'Belgian condition' involved distinctive constraints and opportunities on the pursuit of national and regional economic strategies. What gave the anchoring debate its specificity in a period of general concern about the ability of national states to manage national economies in the interests of national citizens (cf. Jessop 2002) was, of course, the relative fragility of the Belgian state, economy, and sense of citizenship due to the changing articulation of the religious, linguistic, and territorial issues as well as the nature of Belgian bourgeoisie and other classes.

The raid on SG was a shock because it had a crucial role in integrating the Belgian space economy and indirectly controlled over a third of the Belgian economy (Economist 1988). SG tried to stave off this hostile bid by (illegally) increasing its own capital. A week later a Belgian businessman, André Leysen, proposed a redistribution of $S G$ shares in order to provide a Belgian anchor for $S G$ and thus keep part of its economic decision-making power in domestic hands (Cottenier, De Boosere and Gounet 1989, Lamy 1990). But Leysen's co-operation with SG foundered his Leysen's financial and institutional links with the French holding Paribas. Paribas is the long-time rival of Suez, a French holding which in 1987 had established cross-participations with SG as mutual protection against hostile take- 
overs. SG governor Lamy, who felt threatened by Leysens' ambitions, asked Suez to intervene in the acquisition struggle, which it did after some hesitation - inter alia because it feared becoming de Benedetti's next target. After Leysen's failure, Maurice Lippens of AG, Belgium's biggest insurance company, made a second Belgian anchoring attempt. Lippens did reach an agreement with Suez and together they acquired a majority of SG. Belgian anchoring seemed to have been 'realised', albeit with a majority of French shares (van Waterschoot 1988).

The Flemish business magazine Trends, a staunch promoter of Flemish as opposed to Belgian anchoring, initially welcomed the hostile bid on SG (Crols 1988b). For Flemish nationalists and politicians, SG was the symbol of the Belgian francophone economic elite, which, they felt, had always disregarded Flemings and blocked economic opportunities for Flanders. The then Trends chief editor, Frans Crols, wrote that Flemings felt liberated after "having been pushed into a servant's role for 165 years by the rentiers of the Koningsstraat"13 and that "this does not concern the Belgian economy, the raid is concerned with one third of the Belgian economy, the most outmoded and dormant". Trends hailed the acquisition struggle as the final blow to the traditional Belgian francophone holding bourgeoisie and wrote optimistically about the opportunities this new situation offered Flanders. When Suez entered the scene, however, the tone of the Trends commentaries changed (see e.g. Crols 1988a). Its intervention was portrayed as a friend's service within the same traditional francophone establishment and was seized on by Flemish anchorers to attack Belgian anchoring as a Trojan horse intended to keep francophone control over the Flemish economy (Brockmans 1995).

The strategy of Belgian anchoring failed for two main reasons. First, the takeover of $S G$ removed the main anchor and guiding force of the Belgian space economy with the result that it was harder to maintain a coherent strategy. Second, the strategy's national orientation was undermined as the Belgian economy and its social embedding experienced political-economic regionalisation on two fronts. For the Walloon and socialist labour movement blamed the deepening crisis of the Walloon economy on the conservative economic strategy of SG and other Belgian holdings; and many Flemish politicians became disillusioned with the Belgian holdings because they had, it was felt, contributed little to Flemish economic development. 
This regionalisation process undermined the integrity of the Belgian political economy in which SG's political-economic power was embedded and on which its social and symbolic reproduction depended. This regionalisation of hearts and minds explains why the Belgian state found it hard to take effective Belgian anchoring action even though Minister of Finance Eyskens and Minister for Economy Maystadt tried to defend 'vital Belgian interests' against de Benedetti (Crols 1988b; Crols 1988c; Foster 2000; Lamy 1990). For there was no consensus within the government and Belgium's political-economic elite on how to respond to the acquisition struggle.

While the anchoring theme was not retained on the Belgian scale for lack of politicalinstitutional and material supports, it still had strong discursive resonance in Flemish circles. Thus it informed, albeit without great public fanfare, the industrial policy of the Flemish government (1988-1992); this was led for a fourth time by Geens, whom we encountered above as one of the contributors to the Belgian anchoring debate. Flemish anchoring gained a much higher public profile in the next Flemish government, led by minister-president Van der Brande, from 1992, when it became official Flemish government policy. For it became the main economic imaginary promoted by various state agencies and public bodies (Oosterlynck 2006; Van den Brande et al. 1992). The central element in this imaginary was the 'French threat' as French companies were depicted as disproportionately present in 'strategic sectors' of the Belgian economy, such as utilities, banks, insurance companies and holdings (Brockmans 1995; Vlaamse Culturele Koepel and Vereniging Vlaamse Leerkrachten 1995). Flemish anchorers also criticised the extended network of cross-participations that included French investors active in Belgium as well as the French government's steering role in these networks. They even suggested that the French investors were part of a French geo-political strategy intended to bind the Belgian into the French space economy in order to counter the growing influence of a re-unified Germany in constructing Europe. 'Christmas trees' of interacting shareholderships were depicted (Oosterlynck 2005a) and autonomy indexes developed to highlight the perceived French threat (Vlaamse Culturele Koepel and Vereniging Vlaamse Leerkrachten 1995). These indexes reveal Flemish anchorers' mode of calculation. Flanders' autonomy index was allegedly unbalanced because only $18.9 \%$ of companies located there are owned by Flemings, whereas Wallonia's index is balanced because $69.6 \%$ of the companies are in francophone ownership. Francophone here includes 
Walloon, francophone Belgian and French. Thus Flemish anchorers assume some kind of 'natural' affinity between Wallonia, francophone Belgium (which also includes Brussels) and France. The use of this index and similar representations resonated well with Flemish public opinion because the Flemish imaginaries treat all francophone Belgians as having the same values and interests. This is false (Oosterlynck 2005b; Quévit 1978). There have always been tensions between the Walloon movement, which focuses on economic issues and Walloon popular culture, and francophone Brussels, with its strong attachment to French high culture and the defence of the pure French language (Kesteloot 2004). These tensions were reinforced by Walloon frustration with the withdrawal of francophone holding capital from its economy, especially after the strikes against the Unity Law in 1960/1961.

The central position of the perceived French threat in the Flemish anchoring debate is one of two key dimensions of the Flemish economic imaginary, namely, the narration of globalization in Flanders as French colonization. This imaginary proved quite powerful, although de Grauwe's research on FDI between 1980 and 1990 shows that it was based on a selective reading of economic trends (De Grauwe 1992). Although France had the biggest share of FDI in this period, namely $30 \%$, the FDI stream was concentrated in 1988 and 1989, i.e. the years in which Suez bought the Société Générale. Outside these two years, French FDI was in third place behind Germany $(26.4 \%)$ and the Netherlands (21.2\%). Daems similarly notes that the French were responsible for 59 of the 222 take-overs in 1985-90 compared to 57 made by the Dutch (Daems and Van de Weyer 1993). In addition to its exaggerated fear of the French, the Flemish globalization imaginary is based on the idea of mutually exclusive spaces. This second dimension is rooted, like the first, in the demand for linguistic territorial integrity and historic fear of French dominance. The spatially segregated unilingualism and the federal solution to manage a distinctive 'communautarian' politics that are the legacy of the historical struggle of the Flemish movement made the Flemish public opinion and elites more receptive to such imaginaries. Discourses based on the idea that two actors cannot occupy the same place were transmitted from the cultural and political to the economic domain so that the French economic presence was narrated as foreign 'penetration' that would undermine Flemish control over its economy. 
Flemish anchorers unsurprisingly rejected the arguments of Daems and De Grauwe and replied that it was not the relative share of foreign ownership that mattered but its concentration in 'strategic' economic sectors (Oosterlynck 2004b). Strategic importance was variously defined in terms of employment, technological and innovative content, export volume, importance for social capital (e.g. media), importance for underlying competitiveness and strategic needs of Flemish economy, and being part of Flemish industrial heritage (Crols 1995; Oosterlynck 2004a; Vlaamse Culturele Koepel and Vereniging Vlaamse Leerkrachten 1995). Thus strategic importance is a vague idea that can be applied to large parts of the Flemish economy. This is especially clear in the discursive use of the term in the Flemish geo-economic strategy developed by Van den Brande. As minister-president of the new Flemish government, he was looking for ways to link Flemish state formation to Flemish nation formation (Blommaert 2000). With cultural and political autonomy already largely acquired, like many Flemish nationalists, he felt that Flanders also needed economic emancipation. His government's anchoring strategy aimed to transform Flanders from a nation of SMEs without home-grown multinationals into a 'real' economic nation. The government believed that a Flemish majority or controlling ownership was needed to anchor a company (Vlaamse Culturele Koepel and Vereniging Vlaamse Leerkrachten 1995). This approach has been challenged by an alternative strategy based, not on ownership, but on strategic decision-making power. The Flemish economist, Daems, defines this as the ability to determine company strategy (product developments, production technologies and export markets) at local level (Daems 1998; Daems and Van de Weyer 1993). This would be possible because, if companies were to apply corporate governance standards (thereby ending traditional holding structures that enable small minorities to control large blocks of shares), the separation between shareholders and managers would give Flemish management enough autonomy to take strategic decisions.

The preceding paragraph illustrates the existence of two approaches to Flemish anchoring, based on national 'ownership' and corporate governance respectively. These concerns are rooted in different approaches to economic nationalism, i.e., to the role of the national as an intermediate scale of interest between the individual and humanity (Helleiner 2002). The nationalist ontology asks how a given nation can attain power and prosperity, which implies that the people who comprise a nation 
somehow share a common economic fate and have an economic responsibility towards their fellow citizens (Reich 1991). The ownership variant of anchoring strategies is clearly informed by the traditional economic nationalist imaginary in which, in Reich's words, 'the well-being of citizens was linked to the success of the national economy, which depended in turn on the success of its giant corporations' (1991: 34). The corporate governance variant is, for Reich again, more attuned to a new conception of economic nationalism as transformed by globalization. What matters for the nation's future wealth is not a company's nationality but the skills of the local workforce and managers. Thus this variant stresses the importance of local management experience. To ensure that they can manage without shareholder interference, they need good working capital markets, institutional investors and corporate governance. The nationality of the company is of minor importance in this model, which is close to the Anglo-Saxon neo-liberal variety of capitalism.

\section{The institutionalization of the Flemish space economy}

Since its 1830 inception, the Belgian state had to deal with a protracted language conflict and uneven geographical development. The handling of these problems by various social and political actors has produced two regions - Flanders and Wallonia - and locked them into different socio-economic trajectories. This is reflected in the rescaling of Belgium's economic, political, and socio-cultural space. Steadily increasing geo-political rescaling over 150 years of Belgian history, e.g., through political and cultural struggles for regional autonomy and state restructuring, has finally produced the decentralization of Belgian political space. The anchoring debate likewise aims to transform Belgian economic space and is occurring just as geoeconomic rescaling is gathering pace through mechanisms such as European and world market integration, the rise of multinational network firms, and the resurgence of regional economies. This has created the space for pursuing anchoring strategies.

Flemish nationalists have long considered the Flemish economy to be burdened by the overall Belgian space economy (Brockmans 1995). Based on holding capital, first industrial revolution firms, and other traditional sectors, the national economy is associated with the declining industrial spaces in Wallonia. Flemish nationalists criticized the close links between the Belgian political elite and the francophone 
holding bourgeoisie, mainly organized around the Société Générale. These close links were partly based on the relations forged through the Belgian holdings' strong presence in government procurement and infrastructure markets. Following the economic crisis of the 1970s, Flemish nationalists argued that this holding structure was blocking a thorough restructuring of outmoded or crisis-prone affiliated sectors and companies in the Belgian space economy. They also complained that these delays in restructuring were reinforced by the state support that the holding bourgeoisie, the Walloon socialist party and the Walloon trade unions could secure for loss-making companies through their privileged access to the Belgian government. Such subventions were said to divert money from future-directed economic investments, particularly for Flanders. Thus the foreign raid on the SG was applauded by Flemish nationalists because it would destroy the economic base of the Belgian francophone bourgeoisie and cause the disintegration of the Belgian space economy. It would also force $S G$ to restructure and release its control over many (also Flemish) companies, which could then regain their dynamism.

However, the Flemish nationalists also worried that the French acquisitions of SG and several big former state companies in the infrastructure and financial sector (e.g., Distrigas, Belgacom and ASLK) would actually increase francophone control over the strategic sectors of the Flemish economy. This shows that, despite the Flemish nationalist critique of the lack of dynamism and entrepreneurialism of the Belgian holdings, their economic imaginaries share the same traditional economic nationalist identification of national companies with national power. The fact that the French companies were especially targeting Belgian holdings closely related to the government (infrastructure and public procurement) meant that the acquired companies such as Electrabel, Tractebel and Distrigas could not be used as vehicles for Flemish geo-economic and geo-political purposes and/or as the basis for an autonomous Flemish bourgeoisie and the advancement of Flemish economic nationbuilding. This argument is based on the national ownership version of the anchoring strategy. The corporate governance version also questioned the activities of Suez on the grounds that it is a holding company rather than because it is French - and this deviation from the best corporate governance standards mattered more than the nationality and political ties of the companies concerned. 
Despite the discursive resonance (and hence retention) of the Flemish anchoring theme among a significant part of the Flemish political, intellectual and economic elites and its inclusion in the Flemish state project in the first half of the 1990s, the Flemish anchoring discourse has not been consolidated in institutional terms. Economically, the strategy has failed to mobilize the social forces needed to realize a structural transformation of the socio-economic relations of the economy in Flanders. Flemish capital is too small and insufficiently institutionalized to mobilize the financial resources to anchor the privatized state companies or holdings such as Sociéte Générale. The Flemish merchant bank Lessius was a case in point. It was established in 1988 to create the financial structures for Flanders to intervene in important economic events such as the acquisition struggle around SG. Trends' chief editor, Crols, regarded Lessius as a triumphant part of the emerging 'Generale Maatschappij van Vlaanderen' ('SG of Flanders') and said that it signalled the professionalisation of the Flemish business world (Crols 1988d). Lessius never lived up to these expectations. Despite its strong embedding in Flemish economic networks such as the Vlerick network, it failed to gain the size required to play its intended strategic role and was dissolved in 2005 (Desmet 2005). Apart from the lack of institutionalisation of Flemish capital, much of its economic basis lies in the service and non-monopolized industrial sectors that depend on the presence of foreign multinational companies in Flanders. Many Flemish economic decision-makers are thus more interested in maintaining the conditions for the reproduction of foreign monopoly capital in Flanders than in developing an economic basis for the Flemish nation (Roosens 1981). Nor has introducing corporate governance into Flanders increased Flemish strategic decision-making power. Recent economic events (see, for example, Suez's acquisition of Electrabel) show that majority shareholders call the shots, however competent the local managers. More generally, one could argue that economic imaginaries based on a strong sense of boundedness are likely to fail as economic spaces are increasingly linked by cross-border networks.

Despite the apparent failure of the Flemish anchoring strategy to fundamentally reconstitute Flemish economic space, it clearly belongs to a long-term and ongoing historical attempt to rescale economic relations and institutionalize an autonomous Flemish space for strategizing, interest formation and governance in Belgium. This is contributing to the further disintegration of Belgian political space as Flemings try to 
remove the burden of the financial transfers from Flanders to Wallonia caused by its economic crisis and the strength of the Walloon socialist party and trade union. Thus the Flemish economic region-building agenda essentially aims to create a more favourable site of accumulation by eliminating an uncompetitive one. The institutionalization of the Flemish space economy therefore generates a new spatial and institutional fix, deferring the crisis-tendencies of global capitalism (literally) beyond its own boundaries, i.e. into Wallonia. This allows Flanders, at least for now, to better address the competitive pressures of the global market by allowing it to insert the Flemish space economy more favourably than the Belgian space economy into the global strategies of capital. The creation of Flemish 'institutional thickness' (Martin 2000) involves more than creating business assets and competitive institutional arrangements, as soft economic sociologists would have it, and extends to shifting the geographies of capitalist political economy.

\section{Conclusions}

Grossberg, a leading figure in cultural studies, argued that political economy cannot be relied on to develop the potential of the cultural turn, even when it takes the latter seriously, which is rare enough. For it 'always assumes a universal privilege (and a decontextualized singularity) of the economy over politics and culture' (2006: 19). Instead he recommends that the initiative be taken by scholars within cultural studies. Specifically, it should

- engage with economics as discipline and not just with a preferred theorist or theorists;

- address the concrete complexities of economic life, relations and discourses and not just treat theory as an adequate description of economic contexts;

- get involved in collaborative work across disciplines rather than retreat into its own disciplinary boundaries; and

- not unreflectively privilege forms of academic knowledge and knowledge production (2006: 20-21).

We would respond that political economy should follow the same recommendations.

Thus scholars of political economy should 
- engage with cultural studies as a whole and not just with one preferred theorist or school,

- address the complexities of semiosis and explore the discursive and material mechanisms that shape the manner and extent to which 'ideas matter' in political economy rather than merely asserting that they do and/or illustrating this with simple narrative accounts,

- commit themselves to trans-disciplinary interaction or, better, sui generis post-disciplinary research rather than mechanically additive 'multidisciplinary' team work (on different forms of disciplinarity, see Jessop and Sum 2001), and

- not unreflectively privilege forms of academic knowledge and knowledge production but examine in particular common sense economic imaginaries and actually existing struggles over their selection and retention.

The approach to CPE sketched above is one way to respond to these challenges. Indeed, it would seem to correspond almost perfectly to the research agenda set for cultural studies by Grossberg in his provocative call to theoretical arms:

Doing a different kind of - conjunctural - economics involves recognizing that the economy is not only overdetermined but also multiple, relational and discursive. For example, if we are to demystify both economies and economics, we probably need to recognize at least four distinct problematics: (1) economism, or the assumption that the economy (whether we understand as a mode of production, class conflicts, entrepreneurialism, technology, finance or markets) is the motor force of history, has to be criticized with the concept of overdetermination; (2) capitalocentrism -- or the assumption that capitalism in a singular and singularly ubiquitous formation, has to be replaced with a recognition of the multiplicity, not only of capitalisms but also of economic practices and formations (GibsonGraham 1996); (3) productivism or the assumption that production is the essence of economies and therefore, the fundamental; or even the only real source of value, has to be replaced by a recognition of the dispersion and contingency of value; and finally (4) economic essentialism or the assumption that there is a stable and universal distinction between 
economic and non-economic practices or relations, has to be replaced by a recognition, not merely that economic relations are themselves partly discursive, but also that the economic is always a relationally produced category (Grossberg 2006: 21).

We have argued for the cultural turn in economic and political geography (as part of a broader commitment, in our case at least, to a spatio-temporally sensitive political economy) on the grounds that this enables an escape from 'hard political economy', i.e., the naturalization and fetishization of economic categories without regard to their discursively mediated, socially constructed character. But we have also argued that the cultural turn should be combined with critical political economy, which we see as a broad movement rather than one linked exclusively to just one theorist, school, or tradition. This is one way to resist the temptation of 'soft' economic or political geographies characteristic of the new economic sociology and its importation into these fields (for a critique, see Peck 2005). We use the term 'soft' here to describe the subsumption of economic or political categories under general sociological (or cultural) analysis so that the analysis loses sight of the historical specificity and materiality of economics and the dynamics of state power. In developing CPE we have called for serious analysis of variation, selection, and retention in terms of semiotic and extra-semiotic mechanisms. This enables us to distinguish cultural political economy from critical discourse analysis in terms of its 'value-added'. For, whereas critical discourse analysis tends to focus on specific texts, to undertake static comparative analyses of selected texts at different times, or to study linguistic corpora over time, CPE is also interested in the variation, selection, and retention of different discourses and, in this regard, is also concerned with their extra-semiotic as well as semiotic features. Our case study of Belgium illustrates how these mechanisms operate to select, retain, and reinforce specific imaginaries and thereby shape the concrete, contextualized, and contingent dynamics of a particular economy in its specific social and cultural settings as this changes over time. It also shows that, however resonant and persuasive an economic imaginary and its corresponding strategies might be, this is not sufficient to ensure that they can be realized when path-dependent (material as well as semiotic) legacies and the conjunctures (including the capacities and strategies of social forces mobilized behind competing imaginaries) render then more or less 'arbitrary, rationalistic, and willed'. 


\section{References}

Agnew, John, 2000. From the political economy of regions to regional political economy. Progress in Human Geography 24, 101-110.

Barnett, Clive, 2004. A Critique of the cultural turn. In: Duncan, S., Nuala N.C., Johnson, C., and Schein, R.H. (Eds.), A Companion to Cultural Geography. Blackwell, Oxford, pp. 38-48.

Bayart, Jean-François, 1994. L'invention paradoxale de la mode économique. In: Bayart, Jean-François, La réinvention du capitalisme. Éditions Karthala, Paris, pp. 9-43.

Blommaert, Jan, 2000. 'Ik stel vast'. Politiek taalgebruik in het tijdperk van vernieuwing. EPO, Berchem.

Brenner, Neil, 1999. Beyond state-centrism? Space, territoriality and geographical scale in globalisation studies. Theory and Society 28, 39-78.

Brenner, Neil, 2004. Urban governance and the production of new state spaces in western Europe, 1960-2000. Review of International Political Economy 11, 447-488.

Brockmans, Hans, 1995, 200 jaar filiaal. De Franse greep op de Vlaamse economie. Davidsfonds, Leuven.

Campbell, Donald T., 1969. Variation and selective retention in socio-cultural evolution. General Systems 14, 69-86.

Cottenier, Joe, De Boosere, Patrick, and Gounet, Thomas, 1989. De Generale: 18221992. EPO, Berchem.

Crang, Mike, 1997. Cultural Geography. Routledge, London.

Crols, Frans, 1988a. De zichtbare hand. Trends, 9. 21 April.

Crols, Frans, 1988b. Het non-event. Trends, 11.21 January.

Crols, Frans, 1988c. Houd de dief. Trends, 19. 28 January.

Crols, Frans, 1988d. Leysen \& Leysen. Trends, 11. 28 January.

Crols, Frans, 1995. De ideologie van de verankering. In Brockman, Hans (Ed.) 200 jaar filiaal. De Franse Greep op de Vlaamse Economie. Davidsfond, Leuven.

Daems, Herman, 1998. De paradox van het Belgische kapitalisme. Waarom bedrijven financieel goed scoren en toch strategisch slecht spelen. Lannoo,Tielt. 
Daems, Herman, de Weyer, Peter Van, 1993. Buitenlandse invloed in België - de gevolgen voor de strategische beslissingsmacht. Lannoo,Tielt.

Daly, Glyn, 1991. The discursive construction of economic space. Economy and Society 20 (1), 79-102.

Debray, Regis, 1973. Time and politics. In Debray, Regis, Prison Writings. Allen Lane, London, pp. 87-160.

De Grauwe, Paul, 1992. Over Franse kolonisatie en Belgische verankering. Leuvense Economische Standpunten 16.

Desmet, Lieven, 2005. De lessen van Lessius. Trends, 48-50. 1 December. Eyskens, Gaston, 1988. Het laatste gesprek. Herinneringen aan 40 jaar politiek leven. DNB/Uitgeverij Pelckmans, Brussel.

Fairclough, Norman, 2003. Analysing Discourse. Textual Analysis for Social Research. Routledge, London.

Fairclough, Norman, Jessop, Bob, Sayer, Andrew, 2004. Critical realism and semiosis. In Fleetwood, Steven and Roberts, John M. (Eds.), Realism, Discourse and Deconstruction. Routledge, London, pp. 23-42.

Foster, John Bellamy, 2000. Marx's Ecology. Materialism and nature. Monthly Review Press, New York.

Geens, Koen, Hellemans, Frans, Haelterman, Axel, and Bevernage, Piet, 1995. Juridische instrumenten tot verankering van Belgische ondernemingen. Nieuw Tijdschrift voor Politiek, 4-46.

Gibson-Graham, Katherine-Julie, 1996. The End of Capitalism (as we know it): a Feminist Critique of Political Economy. Blackwell, Oxford.

Grabher, Gernot, 1994. Lob der Verschwendung. Sigma, Berlin.

Gramsci, Antonio, 1971. Selections from the Prison Notebooks. Lawrence \& Wishart, London.

Grossberg, Lawrence, 2006. Does cultural studies have futures? Should it? (Or what's the matter with New York?) Cultural Studies 20 (1), 1-32.

Harvey, David, 1982. The Limits of Capital. Blackwell, Oxford.

Helleiner, Eric, 2002. Economic nationalism as a challenge to economic liberalism? Lessons from the 19th century? International Studies Quarterly, 46 (3), 307329.

Hudson, Ray, 2004. Conceptualizing economies and their geographies: spaces, flows and circuits. Progress in Human Geography 28 (4), 447-471. 
Huyse, Luc, 1980. De gewapende vrede. Politiek in België tussen 1945 en 1980. Kritak, Leuven.

Jessop, Bob, 1990. State Theory: Putting the Capitalist State in its Place. Polity, Cambridge.

Jessop, Bob, 1997. A neo-Gramscian approach to the regulation of urban regimes. In Lauria, Mickey (Ed.), Reconstructing Urban Regime Theory. Sage, London, pp. 51-73.

Jessop, Bob, 2002. The Future of the Capitalist State. Cambridge: Polity. Jessop, Bob, 2004. Critical semiotic analysis and cultural political economy. Critical Discourse Studies 1 (2), 159-174.

Jessop, Bob and Sum, Ngai-Ling, 2001. Pre-disciplinary and post-disciplinary perspectives in political economy. New Political Economy 6 (1), 89-101. Jessop, Bob and Sum, Ngai-Ling, 2006. Beyond the Regulation Approach: Putting Capitalist Economies in their Place. Cheltenham: Edward Elgar.

Jones, Martin, 2004. Social justice and the region: grassroots regional movements and 'the English Question'. Space and Polity 8, 157-189.

Kesteloot, Chantal, 2004. Au nom de la Wallonie et de Bruxelles français. Les origines du FDF. Editions Complexe, Bruxelles.

Laclau, Ernesto and Mouffe, Chantal, 1986. Hegemony and Socialist Strategy. Verso, London.

Lamy, René, 1990. Het ware verhaal van een openbaar overnamebod. De strijd om de Generale Maatschappij. Tielt: Lannoo.

Lovering, John, 2001. The coming regional crisis (and how to avoid it). Regional Studies 35, 349-354.

Mandel, Ernest, 1963. The dialectic of class and region in Belgium. New Left Review 20, 5-31.

Martin, Ron, 2000. Institutional approaches in economic geography. In Sheppard, Eric and Barnes, Trevor J. (Eds.) Companion to Economic Geography. Blackwell, Oxford, pp. 77-94

Marx, Karl, 1996. The Eighteenth Brumaire of Louis Bonaparte. In Carver, Terrell (Ed.), Karl Marx: Later Political Writings. Cambridge University Press, Cambridge, pp. 31-127.

Miller, Peter and Rose, Nik, 1993. Governing economic life. Economy and Society 19 (1): 1-31. 
Mitchell, Don, 2000. Cultural Geography: A Critical Introduction, Blackwell,. Oxford. Murphy, Alexander B., 1988. The regional dynamics of language differentiation in Belgium. A study in cultural-political geography. University of Chicago Press, Chicago.

Nonhoff, Martin, 2006. Politischer Diskurs und Hegemonie. Das Projekt "soziale Marktwirtschaft". Transcript, Bielefeld.

Offe, Claus, 1984. Contradictions of the Welfare State. Hutchinson, London.

Oosterlynck, Stijn, 2004a. Interview with Frans Crols. 23 December.

Oosterlynck, Stijn, 2004b. Interview with Hans Brockmans. 23 December.

Oosterlynck, Stijn, 2005a. Interview with Luc Van den Brande. 22 February.

Oosterlynck, Stijn, 2005b. Interview with Michel Quévit. 21 September.

Oosterlynck, Stijn, 2006. The political economy of new regionalism in Belgium: imagining and institutionalising the Flemish regional economy. Lancaster University, Doctoral Thesis.

Paasi, Anssi, 1991. Deconstructing regions: notes on the scales of spatial life. Environment and Planning A 23 (2), 239-56.

Paasi, Anssi, 2002. Place and region: regional worlds and words. Progress in Human Geography 26:802-811.

Peck, Jamie, 2005. Economic sociologies in space. Economic Geography 81 (2), 129-176.

Polanyi, Karl, 1982. The economy as instituted process. In: Granovetter, Mark and Swedberg, Richard (Eds.). The Sociology of Economic Life. Westview, Boulder, pp. 29-51.

Quévit, Michel and Aiken, Michaël, 1978. Les causes du déclin wallon: l'influence du pouvoir politique et des groupes financiers sur le développement régional. Vie ouvrière, Bruxelles.

Reich, Robert B, 1991. The Work of Nations. Preparing Ourselves for 21st Capitalism. Simon \& Schuster, New York.

Reynebeau, Marc, 1995. Het klauwen van de leeuw. De Vlaamse identiteit van de 12de tot de 21 ste eeuw. Uitgeverij Van Halewyck, Leuven.

Roosens, Anton, 1981. Een nieuwe topklasse in Vlaanderen. De Nieuwe Maand 24 (2), 98-108.

Sayer, Andrew, 2001. For a critical cultural political economy. Antipode 33 (4), 637 708. 
Somers, Margaret, 1994. The narrative constitution of identity: a relational and network approach. Theory and Society 23 (4), 605-649.

Sum, Ngai-Ling, 1995. More than a 'War of Words': Identity politics and the struggle for dominance during the recent political reform period in Hong Kong. Economy and Society 24 (1), 68-99.

Sum, Ngai-Ling, 1996. The NICs and competing strategies of East Asian regionalism. In Gamble, Andrew and Payne, Anthony (Eds.), Regionalism and World Order. Macmillan, Basingstoke, pp. 207-46.

Sum, Ngai-Ling, 2000. Globalization and its "Other(s)": Three new kinds of Orientalism and the Political Economy of Trans-border Identities. In Hay, Colin and Marsh, David (Eds.), Demystifying Globalization. Palgrave: Basingstoke, pp.105-126.

Sum, Ngai-Ling, 2004. From Integral State to Integral World Economic Order: Towards a Neo-Gramscian Cultural Political Economy, Working Paper No. 7 of the Cultural Political Economy Research Cluster, Institute for Advanced Studies, Lancaster University, http://www.lancs.ac.uk/ias/polecon/index.htm

Sum, Ngai-Ling, 2005. 'From Regulation Approach to Cultural Political Economy', Workpackage 1, Discussion Paper on the EU Framework 6 DEMOLOGOS project, http://demologos.ncl.ac.uk/wp/wp1/disc.php

Swyngedouw, Erik, 1997. Neither global nor local: "glocalization" and the politics of scale. In Cox, Kevin R. (Ed.) Spaces of Globalisation. Guilford Press, New York, pp. 137-166.

Thrift, Nigel, 2004. Knowing Capitalism. Sage, London.

Van den Brande, Luc, De Batselier, Norbert, Kelchtermans, Theo, Weckx, Hugo, Van den Bossche, Luc, Sauwens, Johan, Detiège, Leona, and Demeester-De Meyer, Wivina, 1992. Vlaanderen-Europa 2002.

Van Istendael, Geert (Ed.) 1993. Het nut van België. Atlas, Antwerp.

van Waterschoot, Jerry, 1988. Speeltijd is voorbij. Financieel-Economische Tijd. 25 February.

Vandermotten, Christian, Piet Saey, and Christian Kesteloot, 1990. België in stukken: bestaan Vlaanderen en Wallonië echt? In Subite, Mort (Ed.) Barsten in België: een geografie van de Belgische maatschappij. EPO, Berchem.

Vlaamse Culturele Koepel, and Vereniging Vlaamse Leerkrachten, 1995.

Verankering voor beginners. Herman Gevaert, Brugge. 
Wickham, Gary, 1987. Power and power analysis: beyond Foucault? Economy and Society 12 (4), 468-498.

Witte, Eis, Craeybeckx, Jan, and Meynen, Alain, 1997. Politieke geschiedenis van Belgie van 1830 tot heden. VUB Press, Brussel. 


\section{Endnotes}

1 This paper has benefited from our participation in the 'Cultural Political Economy' workshop organized by Ngai-Ling Sum and funded by Lancaster University's Institute for Advanced Studies (2004-2006), in the long-established 'Language, Ideology, and Power' group at Lancaster, and from more general discussions with Norman Fairclough, Andrew Sayer, and Ngai-Ling Sum over many years.

${ }^{2}$ On spatio-temporal fixes, see Jessop (2002).

${ }^{3}$ The Lancaster CPE approach was prefigured in Jessop's neo-Gramscian approach to the state and neo-Gramscian version of the regulation approach; and in Sum's work on the discursive and material dimensions of the 1997 transfer or Hong Kong to mainland China (Sum 1995) and East Asian economic strategies (Sum 1996, 2000). For a preliminary statement, see Jessop and Sum (2001).

${ }^{4}$ For example, Nonhoff (2006) develops an interesting analysis of the hegemony of the social market economy in Germany and its re-invention in neo-liberal guise. Our approach nonetheless differs strongly from the sort of post-Marxist discourse analysis advocated by Laclau and Mouffe (1986), which one-sidedly valorizes discourse without regard to extra-discursive mechanisms of selection and retention. For an interesting illustration of the lack of recognition of the CPE approach in any of its manifestations, see the general critique of the cultural turn in political economy by a leading figure in cultural studies, Lawrence Grossberg, in which he argues that cultural studies cannot take the path of political economy, even when it tries to take the cultural turn seriously, which is rare enough. In the end, it sees culture as a medium into which the economy is translated and through which it moves, but which has no real effects of its own' (2006: 19). We claim that CPE can meet this challenge (see below).

${ }^{5}$ Polanyi (1982) distinguished substantive economic activities involved in material 'provisioning' from formal (profit-oriented, market-mediated) economic activities. The leading economic imaginaries in capitalist societies ignore the full range of substantive economic activities in favour of a focus on formal economic activities.

${ }^{6}$ Indeed, there is no economic imaginary without materiality (Bayart 1994: 20-1).

${ }^{7}$ Although all practices are semiotic and material, the relative causal efficacy of these elements will vary.

${ }^{8}$ Horizontal refers here to sites on a similar scale (e.g., personal, organizational, institutional, functional systems) and vertical refers to different scales (e.g., micro-macro, local-regional-nationalsupranational-global). The use of both terms must be relative and relational.

${ }^{9}$ A web of interlocution comprises metanarratives that reveal linkages between a wide range of interactions, organizations, and institutions and/or help to make sense of whole epochs (Somers 1994: 614).

${ }^{10}$ On discursive selectivity, see Hay 1996 and Somers 1994; on structural selectivity, see Jessop 1990. 
${ }^{11}$ Space economy is a historically specific spatialization of economic relations.

12 The relativization of scale involves a crisis of the primacy of the national scale and associated complex process of the rescaling of political and economic relations (Brenner 1999; Brenner 2004; Jessop 2002; Swyngedouw 1997).

${ }^{13}$ The headquarters of SG were located in Koningsstraat. 